\title{
Pensononowoor
}

2017, vol. 78, 63-74

http://dx.doi.org/10.12657/denbio.078.007

\author{
Angel Romo, Grzegorz Iszkuło, Mohammed Seghir Taleb, \\ Łukasz Walas, Adam Boratyński*
}

\section{Taxus baccata in Morocco: a tree in regression in its southern extreme}

This work is dedicated to the memory of Pierre Quézel, who was one of the pioneers in the study of the forests and vegetation in the Mediterranean biogeographical area.

Received: 23 January 2017; Accepted: 20 April 2017

\begin{abstract}
The knowledge on chorology of species is basic for biogeographic and ecological studies and for conservation actions. The data on the chorology of Taxus baccata in Morocco have not been studied.

The bibliographic resources, herbarium material, unpublished data of several botanists and the authors' field notes have been reviewed. Two yew populations on Jbel Lakrâa in the Rif and near Bekrit in the Middle Atlas were measured to verify demographic structure and health conditions. The Maxent model of predicted habitat based on bioclimatic variables was used to evaluate the potential geographic range of $T$. baccata. The species occurs in the mountain areas of northern Morocco: in the Rif, the Middle and High Atlas, at altitudes between (500) 1200 and 2000 (2350) m. In the High Atlas, it reaches its southernmost locations within the geographic range. The populations represented by the highest number of individuals are found in the Western Rif and Middle Atlas, while from the High Atlas only single, isolated individuals are known. The yew occurred preferably in forests of Cedrus atlantica, Abies maroccana, groves of Betula fontqueri, Ilex aquifolium and Prunus lusitanica and in riparian forests located in narrow gorges. Seedlings were observed only at single localities. The population of $T$. baccata in the Rif presented a good health condition with successful regeneration, while the population in the Middle Atlas was in a much worse state, where only 4-8 $\mathrm{m}$ high yews were observed, without natural regeneration. The Maxent model of predicted habitat, based on bioclimatic variables, suggests that T. baccata could occur today in much broader mountainous areas in Morocco, especially in the Rif and Middle Atlas. However, the progressive decline of this species in Morocco indicates the significant importance of other factors on yew distribution, including microsite conditions and human pressure. Taxus baccata in Morocco is in regression at most of its localities and should be treated as a vulnerable species. Measures to ensure the yew's conservation are needed, especially at its southernmost localities in the High Atlas.
\end{abstract}

Keywords: dakhs, ecology, forestry, phytogeography, plant conservation, niche modelling

Addresses: A. Romo, Botanical Institute of Barcelona, Consejo Superior de Investigaciones Científicas, IBB-CSIC-ICUB, Passeig del Migdia s/n., 08038 Barcelona, Spain, e-mail: a.romo@ibb.csic.es G. Iszkuło, Institute of Dendrology, Polish Academy of Sciences, Parkowa 5, 62-035 Kórnik, Poland, Faculty of Biological Sciences, University of Zielona Góra, Prof. Z. Szafrana 1, 65-516 Zielona Góra, Poland, e-mail: iszkulo@man.poznan.pl M. Seghir Taleb, Département de Botanique et Ecologie Végétale, Institut Scientifique, Université Mohammed V-Agdal, Avenue Ibn Batouta, B.P. 703, Agdal, Rabat, 10106 Maroc

Ł. Walas, Institute of Dendrology, Polish Academy of Sciences, Parkowa 5, 62-035 Kórnik, Poland A. Boratyński, Institute of Dendrology, Polish Academy of Sciences, Parkowa 5, 62-035 Kórnik, Poland, e-mail: borata@man.poznan.pl

*Corresponding author 
This work is dedicated to the memory of Pierre Quézel, who was one of the pioneers in the study of the forests and vegetation in the Mediterranean biogeographical area.

\section{Introduction}

Taxus baccata L. is an evergreen, slow growing and long-living tree (Thomas \& Polwart, 2003). It is dioecious, with single monoecious individuals reported from the eastern parts of its geographic range (Pridnya, 1984; Iszkuło \& Jasińska, 2004). The geographic range of the species covers central and southern Europe (Meusel et al., 1965; Jalas \& Suominen, 1973), Anatolia, the Caucasus and Elburz Mountains in Asia (Browicz, 1982), north-western Africa (Charco, 2001), Madeira and the Azores (Schirone et al., 2010; Vessella et al., 2013). In the Mediterranean region (sensu Takhtajan, 1986), T. baccata occurs in the mountains, as do most of the other Euro-Siberian species (García et al., 2000). In Morocco, the species represents the Euro-Siberian geographic element of the flora (Benabid, 1983a; Fenanne \& Ibn Tattou, 2005). The presence of T. baccata in Morocco has been recognized from the times of Jahandiez and Maire (1931) and Emberger (1938). The yew was reported from the area between 'Beni Jaled and Beni Syel' (Ruiz de la Torre, 1956), more precisely from the Rif, the central part of the Middle Atlas and the High Atlas (Fennane \& Ibn Tattou, 2005). The simplified maps of distribution of $T$. baccata in Morocco are known either from the general maps of the species range (Meusel et al., 1965; Hultén \& Fries, 1986) or from the only known specific map of the species' distribution in North Africa (Charco, 2001), which is rather simplistic when compared with data of Moroccan yew localities dispersed through the literature.

Taxus baccata is known in Morocco in Arabic as dakhs / dakhch / dags / t'akhch / tags and in the Berber language as adr'am / imerwel / imeruel / igen / igui / sigeh / sigel / tarek / terch / tiffuzel (Ruiz de la Torre, 1956; Cortés et al., 2000). It has been utilized as a medicine for rheumatism (Bnouham et al., 2006) and for diabetes treatment (Benkhnigue et al., 2014), but its use is not exempt from danger in both cases. The arils, once free of the toxic seed, are edible for human beings and possess laxative and cough relieving properties (Bellakhdar, 1997). Besides the medicinal application, the wood of the yew is very valuable, being one of the most compact and dense-grained, reddish in colour, resistant to rotting and free of resin bleed, as well as being easy to fell. It is sought after by lathe workers and makers of musical instruments and in carpentry (Charco, 2007). The yew has also been widely used as an ornamental species, since it is very tolerant of pruning, thanks to its numerous latent buds (Thomas \& Polwart, 2003). The slow growth, weak competitive ability, deer pressure, high wood quality, medicinal uses and leaves toxic to livestock are the reasons for the decline of forests and even individual specimens of T. baccata (Charco, 2007; Iszkuło et al., 2016). Its current IUCN (2012) status recognizes it as endangered, not only in Morocco. The yew has declined everywhere and its populations have become isolated and even extinct in several regions (Myking et al., 2009; Schirone et al., 2010; Devaney et al., 2014; Iszkuło et al., 2016). Recognition of the current state of the species at its localities on its southern limit of distribution in Morocco is basic, and one of the most important steps towards its successful conservation. Consequently, the aim of the present work was (1) to collect all possible data on occurrence of $T$. baccata in Morocco, (2) to review accessible data concerning ecological conditions at particular localities (altitude, exposition, slope inclination, substratum type, relief form, plant community), (3) to analyse potential distribution based on presence-only observations, (4) to analyse in the field some of the localities as regards the number of individuals, the sex ratio, the height and diameter structure of the population, the presence of a young generation (seedlings and saplings) and (5) to evaluate the threat in the regions of occurrence and in the whole country.

\section{Materials and Methods}

\section{Data sources}

The localities were retrieved from the literature and the labels of herbarium material. The plant collections most important for the Maghreb are preserved in herbaria of the Botanical Institute of Barcelona (BC), Biodiversity Centre of Barcelona (BCN), British Museum (BM), Botanical Garden of Edinburgh (E), University of Granada (GDA), Kew Gardens (K), Botanical Garden of Madrid (MA), University of Malaga (MGC), University of Reading (RNG) and University of Seville (SEV). The mentioned herbaria conserve the basic collections for Morocco from the moment botanical exploration of the country started during the first decades of the $20^{\text {th }}$ century.

During a number of the authors' expeditions which started in 1985, the numerous localities of T. baccata were visited and many field notes on the species' occurrence and conditions were made. The unpublished data on the occurrence of the yew from several botanists were also used. Finally, the information from the Moroccan Forest Office substantially supplemented the data concerning the yew's 
occurrence and, additionally, was used to verify gathered data from the other sources.

All the data collected were stored in one database, arranged in geographic order and standardized in order to retrieve comparable references on the conditions of T. baccata's occurrence. We were looking especially for data on the substrate rock, using several simple categories, such as: calcareous rocks (LM), basalts (BA), sandstones (SA), siliceous rocks (SI) and undefined (IN), when not indicated in the source information. We also reviewed the basic relief forms, such as convex ones including rocks (CX), slopes (SL) and concave forms, including gutters on the slopes, couloirs and stream valleys (CC). The temperature and humidity of the sites are in great degree affected by aspect. We determined it for particular localities using the main and intermediate geographic directions (N, NE, E and others). These types of data were frequently used in the literature and on herbarium labels to describe the localities, which were also determined during our field investigations, and thus could be analysed. The number of individual trees, including seedlings and saplings, injuries and possible threat was estimated at every visited locality. The climatic conditions for particular localities were retrieved from the WorldClim database (www.worldclim.org) with application of DIVA-GIS software for each point using 30 arc-seconds resolution interpolated climatic surfaces (Hijmans et al., 2005). Prediction of range was performed using the Maxent program version 3.3.3k (Phillips et al., 2006). It uses a maximum entropy model to estimate a probability distribution of species and create a model of habitat suitability, which varies from 0 (lowest) to 1 (highest). The program uses data related to sites, in which known populations exist. Bioclimatic variables used for predictions were also downloaded from the WorldClim database (Hijmans et al., 2005). The Maxent parameters used in analysis: maximum number of background points was 10000 , maximum number of iterations 500, convergence threshold $10^{-5}$. Output format was logistic and replicated run types were crossvalidated. To evaluate results of model, we used Receiver Operating Characteristic (ROC) curve. Value of Area Under the Curve (AUC) lower than 0.6 means that result of prediction is not much better than random; value 1.0 shows that model prediction is excellent.

\section{Population structure}

To recognize the height and diameter structure, sex ratio and health conditions, the two numerous T. baccata populations, namely on Jbel Lakrâa in the western Rif and at Bekrit in the Middle Atlas were studied and measured on plots covering 0.94 and 0.19 ha, respectively. The height and diameter $1.3 \mathrm{~m}$ above ground level (d.b.h.) of every yew individual on the plots were measured. Simultaneously, the sex of every yew was determined using the presence of male or female structures. Then the number of stems on every yew individual was counted. The injuries were estimated according to the following scale: without visible necrosis and reduction in number of needles (1), apex of the leaves yellowish on the greater part of the tree crown (2), greater part of the branches with necrotic (dry) needles (3), greater part of the trunk with necrosis (4) and dead specimen (5).

\section{Results}

\section{Distribution and occurrence conditions}

\section{Rif}

In total, 13 localities of $T$. baccata were reported from the West and Central Rif (Fig. 1), from an

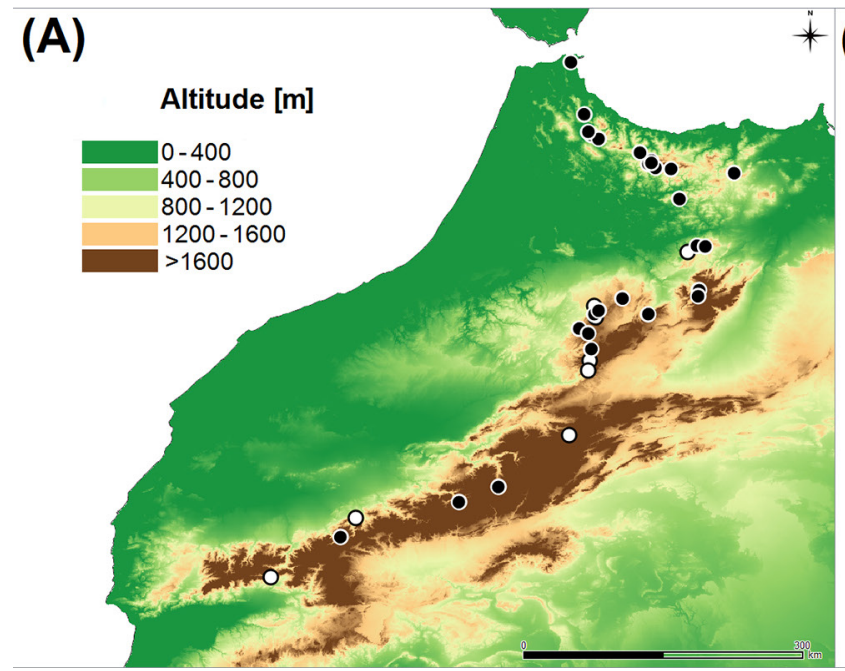

\section{(B)}

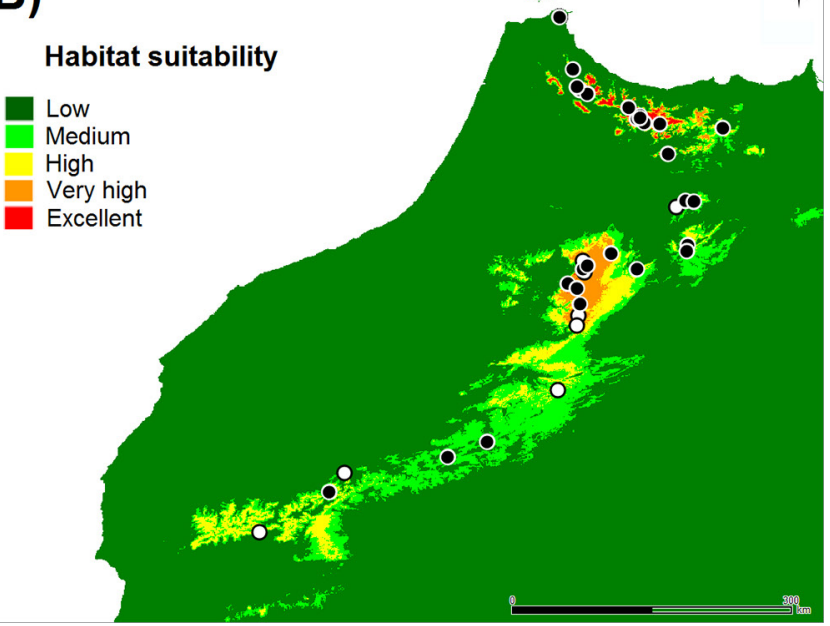

Fig. 1. Distribution of Taxus baccata in Morocco: A - superimposed on altitude map, B - superimposed on climate habitat suitability map. Black dots: verified populations, white dots: data from the literature 
Table 1. Comparison of climatic conditions of Taxus baccata populations from the Rif, Middle Atlas and High Atlas in Morocco. Different letters (a,b) represent significant differences between average values of climate factors for mountain ranges (Tukey-Kramer HSD test, $\mathrm{P}=0.05$ ); SE - Standard Error

\begin{tabular}{|c|c|c|c|c|c|c|c|c|c|c|c|c|}
\hline \multirow{2}{*}{ Climate factor } & \multicolumn{4}{|c|}{ Rif } & \multicolumn{4}{|c|}{ Middle Atlas } & \multicolumn{4}{|c|}{ High Atlas } \\
\hline & Mean & $\pm \mathrm{SE}$ & Min & Max & Mean & $\pm \mathrm{SE}$ & Min & Max & Mean & $\pm \mathrm{SE}$ & Min & Max \\
\hline Temperature $\left[{ }^{\circ} \mathrm{C}\right]$ & $10.99^{a}$ & 0.51 & 9.10 & 15.45 & $10.99^{a}$ & 0.24 & 9.78 & 12.65 & $10.74^{\mathrm{a}}$ & 0.81 & 9.08 & 12.17 \\
\hline $\begin{array}{l}\text { Maximum temperature of warmest } \\
\text { month }\left[{ }^{\circ} \mathrm{C}\right]\end{array}$ & $28.46^{\mathrm{b}}$ & 0.23 & 27.20 & 29.40 & $30.70^{\mathrm{a}}$ & 0.23 & 29.20 & 32.70 & $31.04^{\mathrm{a}}$ & 1.32 & 27.30 & 33.50 \\
\hline Average yearly precipitation [mm] & $971.0^{\mathrm{a}}$ & 33.1 & 706.3 & 1112.0 & $646.8^{\mathrm{b}}$ & 46.0 & 408.0 & 870.0 & $533.5^{\mathrm{b}}$ & 44.5 & 437.0 & 637.0 \\
\hline Precipitation of wettest quarter [mm] & $428.5^{\mathrm{a}}$ & 25.7 & 211.0 & 532.0 & $234.6^{\mathrm{b}}$ & 19.1 & 141.0 & 333.0 & $200.7^{b}$ & 17.3 & 166.0 & 240.0 \\
\hline Precipitation of driest quarter [mm] & $30.8^{\mathrm{a}}$ & 2.9 & 9.0 & 45.0 & $45.7^{\mathrm{b}}$ & 1.52 & 31.0 & 53.0 & $31.0^{\mathrm{ab}}$ & 3.2 & 24.0 & 37.0 \\
\hline
\end{tabular}

altitude of $500 \mathrm{~m}$ on Jbel Moussa to $1950 \mathrm{~m}$ on Jbel Azrou Akechar, and $2000 \mathrm{~m}$ on Jbel Tidirhine in the Central Rif. The highest number of localities detected lies between 1500 and $1800 \mathrm{~m}$ (Fig. 2). The yew occurred in the temperature range from 9.1 to $14.5^{\circ} \mathrm{C}$, an average of $11.0^{\circ} \mathrm{C}$, and the sum of yearly rainfall was between 706 and $1112 \mathrm{~mm}, 971 \mathrm{~mm}$ on average, this being significantly higher compared to the populations in the Middle and High Atlas (Table 1). Occurrence of the species is connected with soils developed from rocks containing calcium (nine localities). It was also recorded from three localities on substrata developed from siliceous rocks in the central part of the Rif (Suppl. 1).

Generally, Taxus baccata was observed in the Rif on north or close to north-facing slopes (Fig. 3). The species occurred mainly in the form of single individuals or small groups of old specimens dispersed in forests of Abies maroccana Trab. and/or Cedrus atlantica (Endl.) G.Manetti ex Carrière, and sometimes also along stream valleys in association with Prunus

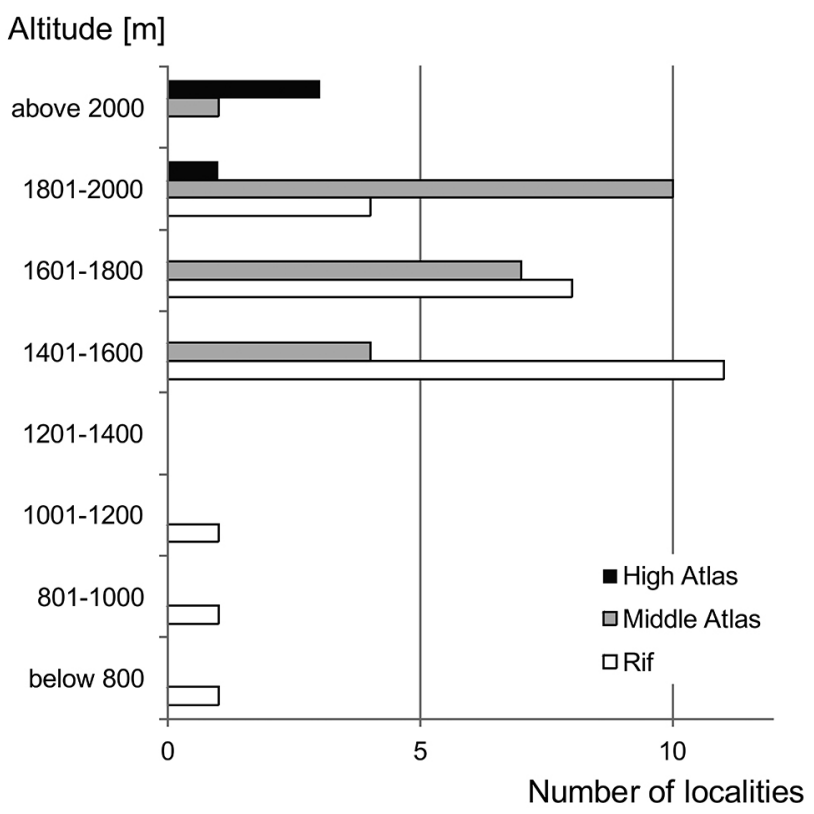

Fig. 2. Altitudinal range of Taxus baccata in the Rif, Middle Atlas and High Atlas in Morocco on the basis of all accessible data lusitanica L. Predominantly, seedlings and saplings were not registered, either in the published data, or

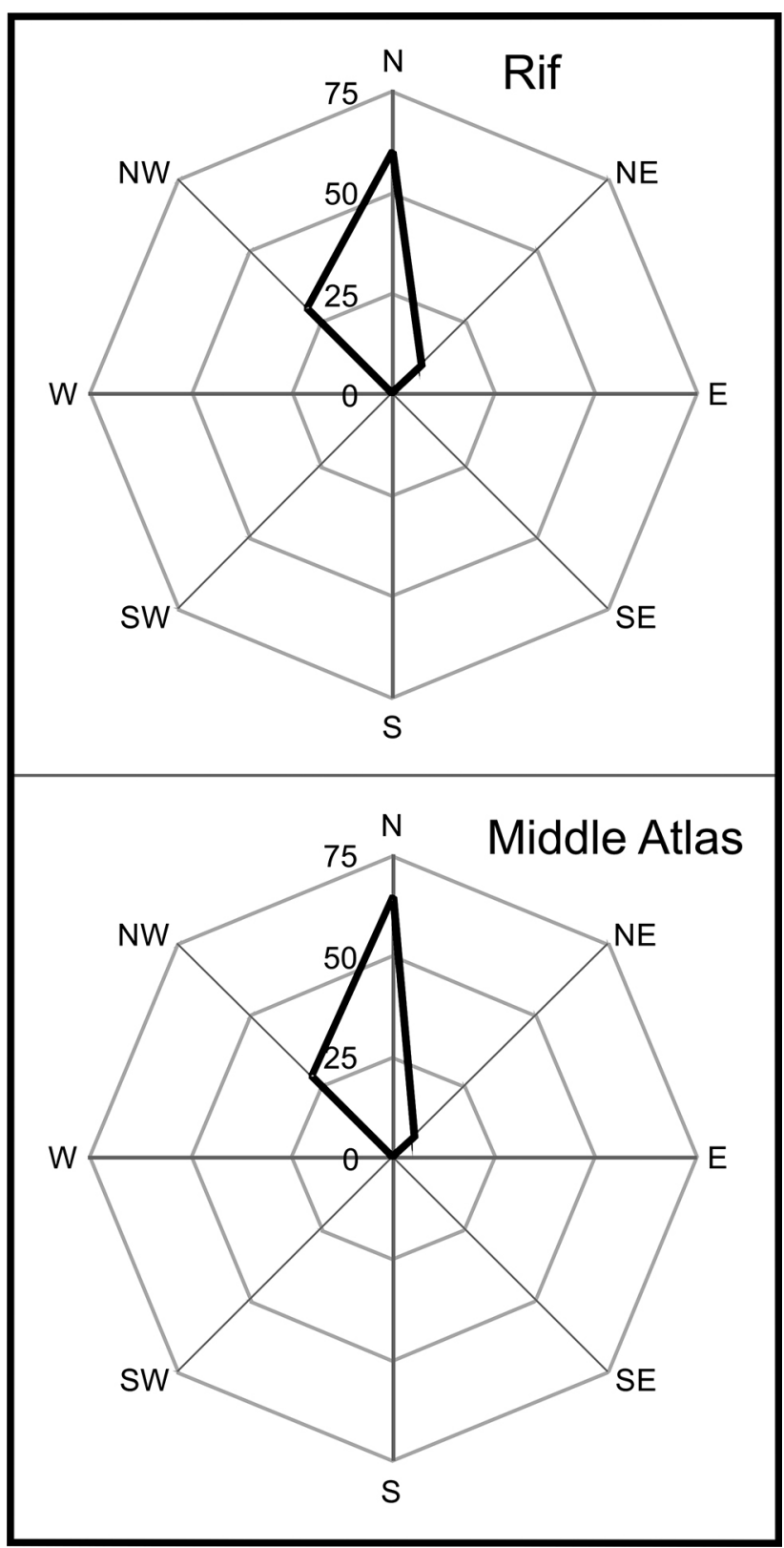

Fig. 3. Percentages of localities of Taxus baccata on particular expositions in the Rif and Middle Atlas (after data from Suppl. 1) 


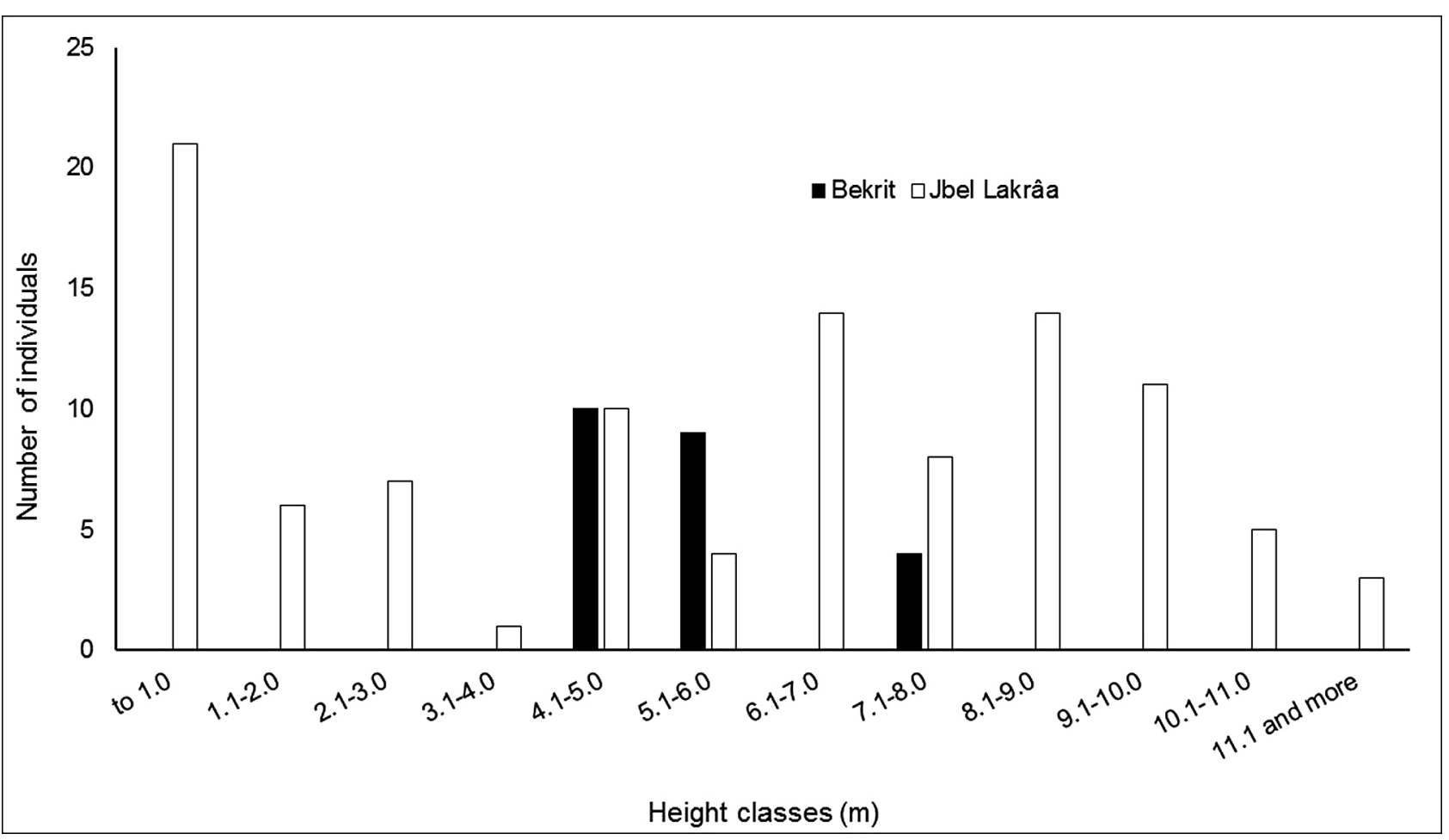

Fig. 4. Distribution of yews in height classes in Bekrit and Jbel Lakrâa

observed by forest officers and/or during our field investigations. Seedlings were observed only in the Talassemtane National Park on Jbel Tissouka and Jbel Lakrâa (Fig. 4).

\section{Middle Atlas}

In total, 16 localities were reported from the Middle Atlas. The yew was observed at particular locations as a rule in single or not numerous individuals, no more than a dozen or so. The localities were reported from altitudes between 1400 and $1500 \mathrm{~m}$ on Jbel Tazekka to $2080 \mathrm{~m}$ in the Aïn Kahla Forest district (Suppl. 1), with the largest number of data from between 1800 and $2000 \mathrm{~m}$ (Fig. 2). Occurrence of T. baccata is connected with sites developed on the northern slopes (Fig. 3) of limestone, and in some places, also of basalt rocks. A number of individuals grew directly in rock fissures or on precipitous slopes covered with stones or stony gravels with scarce plant cover. Populations occurred in the temperature range from 9.8 to $12.6^{\circ} \mathrm{C}$, an average of $11.0^{\circ} \mathrm{C}$, and with the sum of yearly rainfall between 408 and 870 $\mathrm{mm}, 647 \mathrm{~mm}$ on average (Table 1). The most abundant populations, found at the vicinities of Azrou and Ifrane, were detected in cedar forest on calcareous rocks, quite exclusively on the slopes exposed to the north, or sometimes also in stream ravines. In the Rif, as also in the Middle Atlas, T. baccata is represented mostly by adult, in places even large old, trees but without a young generation. Seedlings and saplings were found only in the Forêt d'Aïn Kahla (Suppl. 1). The trees in several places revealed injuries and/or signs of pruning or lopping of the branches. Felled trees were also observed, as in the population near Ras-el-Ma (Suppl. 1).

\section{High Atlas}

The southernmost localities of T. baccata in Morocco were reported from the High Atlas (Fig. 1). The data concern only localities between 1900 and 2350 $\mathrm{m}$, in the temperature range from 9.1 to $12.2^{\circ} \mathrm{C}$, an average of $10.7^{\circ} \mathrm{C}$, and the sum of yearly rainfall between 437 and $638 \mathrm{~mm}, 534 \mathrm{~mm}$ on average (Table $1)$. We were unable to confirm in the field three localities, in spite of specific searching during several expeditions. Two of them, from the vicinity of Zaouiat Ahansal and from M'Goun, were found during recent decades by Alain Dobignard (personal communication) and thus in all probability still exist, as is the case of one not precisely reported from the East Middle Atlas. The other three should probably be treated as historical data (see Suppl. 1). At the two localities known, only a few old specimens were observed (courtesy of A. Dobignard). On M'Goun two old yews were found on inaccessible rocks, beyond goat and shepherd influence. In the Gorges de l'Akka n'Tazert near Zaouiat Ahansal a few old, but mutilated, yews were observed in Buxus sempervirens L. plant association (Suppl. 1). These are the only yew trees known until now in the High Atlas, and at the same time the southernmost in the whole geographic range of the species. 


\section{Predicted habitat}

The model created using the Maxent program allows us to assume that environmental conditions in the Middle Atlas and Rif are optimal for the yew, while conditions in the High Atlas, especially in the southern part, are quite good (Fig. 1B). The largest contribution to the Maxent model had a mean diurnal range of temperature (26.9\%), minimum temperature of coldest month $(19.5 \%)$, precipitation seasonality $(14.6 \%)$, mean temperature of coldest quarter $(12.7 \%)$, precipitation of coldest quarter $(9.8 \%)$ and annual mean temperature $(7.8 \%)$ (Table $3)$. Evaluation of the model showed that the prediction was very good. The average test AUC for the replicate runs was 0.989 and the standard deviation was 0.015 .

\section{Population structure}

In Jbel Lakrâa (Rif) T. baccata grew in a forest of A. maroccana, with the second tree's floor composed of Quercus ilex L., while in Bekrit (Middle Atlas) it occurred in riparian forest located in narrow gorges. A total of 23 and 83 individuals were found on the study plots in Bekrit and Jbel Lakrâa, respectively (Table 2). The yew density on the plots was 123 individuals per hectare in Bekrit and 95 in Jbel Lakrâa. The results were 12 females, 10 males and one individual without sex determinants in Bekrit, and 29 females, 50 males and four indeterminate in Lakrâa. Yews in Jbel Lakrâa were higher compared to Bekrit, but the latter had a greater diameter. Males were higher in Bekrit and lower in Jbel Lakrâa, compared to females. Males had a greater diameter compared to females in both populations. However, height and diameter were not significantly different between sexes (Student's t-test, $\mathrm{P}=0.05)$. Males had more stems in both populations compared to females (Table 2).

The largest number of individuals was found in the lowest height class (to $0.24 \mathrm{~m}$ ) in Jbel Lakrâa (Fig. 4) and between 6.1 and $10.0 \mathrm{~m}$. Classes 3.1-4.0 $\mathrm{m}$ and 5.1-6.0 $\mathrm{m}$ were less numerous than the other. The yew individuals in Bekrit were 4.1-8.0 m high (Fig. 4).

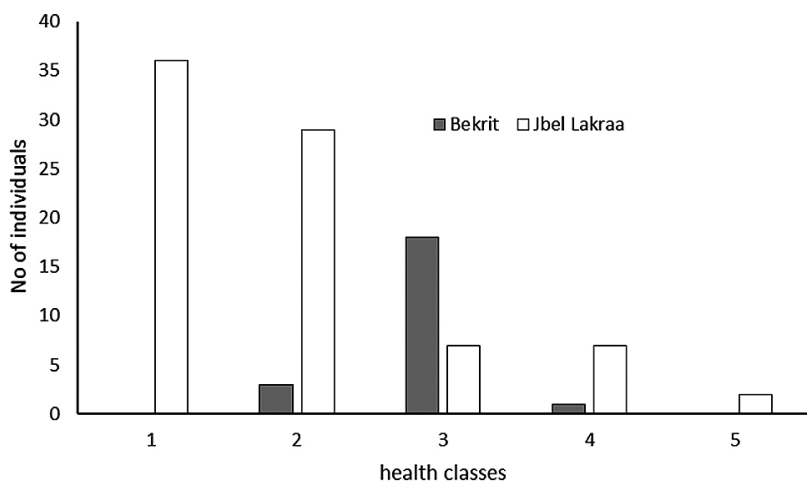

Fig. 5. Number of Taxus baccata individuals in health classes ( 1 - without injuries, 2 - yellowish needle apex on the greater part of the tree crown, 3 - greater part of the branchlets with needle necrosis, 4 - greater part of the trunk with necrosis, 5 - dead specimens)

The population in Jbel Lakrâa was in quite good health conditions, with about $80 \%$ of individuals without or with only a low level of damage (the first and second class); however, several dead and strongly damaged trees were noted (Fig. 5). In Bekrit, most of the individuals $(82 \%)$ were in the third health class (Fig. 5), with needle necrosis on the greater part of the branches.

\section{Discussion}

\section{Distribution}

The present distribution of T. baccata occurrence in Morocco is discontinuous (Fig. 1A), with the geographic range divided into separated populations and/or individuals, depending on the conserved woody vegetation communities. Single individuals are known from the High Atlas (Taleb \& Fennane, 2008), but accessible fossil data indicate its broader distribution in this mountain range in the past (Ruiz et al., 2014). As a species occurring together with $C$. atlantica and $A$. maroccana, T. baccata was more broadly distributed in the Rif (Zapata et al., 2013) and Middle Atlas up to the middle Holocene (Lamb \& van der Kaars, 1995; Cheddadi et al., 1998; Fletcher

Table 2. Mean (and standard error) of measured characteristics in two populations of Taxus baccata in Morocco. Height (H) and diameter (D 130) were not significantly different between sexes (Student's t-distribution, $\mathrm{P}=0.05$ )

\begin{tabular}{|c|c|c|c|c|}
\hline Population & & Females & Males & Indetermined \\
\hline \multirow[t]{4}{*}{ Bekrit } & $\mathrm{N}$ & 12 & 10 & 1 \\
\hline & $\mathrm{H}[\mathrm{m}]$ & $5.07(0.23)$ & $5.90(0.43)$ & 5.70 \\
\hline & D $130[\mathrm{~cm}]$ & $16.98(1.88)$ & $20.57(2.20)$ & 20.35 \\
\hline & No of stems & $3.5(0.8)$ & $4.5(1.2)$ & 2.0 \\
\hline \multirow[t]{4}{*}{ Jbel Lakrâa } & $\mathrm{N}$ & 29 & 50 & 4 \\
\hline & $\mathrm{H}[\mathrm{m}]$ & $7.80(0.33)$ & $6.89(0.47)$ & $5.43(1.86)$ \\
\hline & D $130[\mathrm{~cm}]$ & $13.43(1.35)$ & $14.77(1.43)$ & $8.04(2.61)$ \\
\hline & No of stems & $2.0(0.3)$ & $2.0(0.2)$ & $2.0(0.7)$ \\
\hline
\end{tabular}


Table 3. Contribution of bioclimatic variables in the model of predicted habitat (averages of 10 replicate runs)

\begin{tabular}{lc}
\hline \multicolumn{1}{c}{ Variable } & $\begin{array}{c}\text { Contribu- } \\
\text { tion [\%] }\end{array}$ \\
\hline Mean diurnal range of temperature (BIO2) & 26.9 \\
Minimum temperature of coldest month (BIO6) & 19.5 \\
Precipitation Seasonality (Coefficient of Variation) & 14.6 \\
(BIO15) & 12.7 \\
Mean temperature of coldest quarter (BIO11) & 9.8 \\
Precipitation of coldest quarter (BIO19) & 7.8 \\
Annual mean temperature (BIO1) & 2.9 \\
Isothermality (BIO3) & 2.2 \\
Precipitation of wettest quarter (BIO16) & 1.4 \\
Precipitation of wettest month (BIO13) & 1.4 \\
Precipitation of driest quarter (BIO14) & 0.3 \\
Precipitation of driest quarter (BIO17) & 0.1 \\
Precipitation of warmest quarter (BIO18) & 0.1 \\
Mean temperature of warmest quarter (BIO10) & 0.1 \\
Temperature annual range (BIO7) & 0.1 \\
Mean temperature of wettest quarter (BIO8) & 0.1 \\
Annual precipitation (BIO12) & 0 \\
Temperature seasonality (SD*100) (BIO4) & 0 \\
Maximum temperature of warmest month (BIO5) & 0 \\
Mean temperature of driest quarter (BIO9) &
\end{tabular}

\& Sánchez Goñi, 2008; Cheddadi et al., 2016). The model of predicted habitat, generated using the Maxent program, suggests that T. baccata could occur today in many mountainous areas in Morocco, especially in the Rif and Middle Atlas (Fig. 4B).

Most of the currently known yew localities have a relict character due in part to contraction of the species' range resulting mainly from climate aridification (Lionello, 2012; Lionello et al., 2014), which restricted the area with suitable site conditions for the species. The reduction of the population of T. baccata during the last $4-5,000$ years has also been due to human pressure, firstly as a result of elimination of the forests when humans colonized the North African area (Lamb et al., 1991; Charco, 2007), afterwards during more recent times resulting from yew wood being used for carpentry and furniture making (Charco, 2007), the medicinal utilization of various parts of the plants (Bellakhdar, 1997; Bnouham et al., 2006; Benkhnigue et al., 2014), cutting trees to protect livestock against intoxication (Bnouham et al., 2006) and intensive browsing by goats, which can totally eliminate yew seedlings (Benabid, 1983b; Charco, 2007; Farris \& Filigheddu, 2008).

From a geographic point of view, the most interesting are the marginal localities of $T$. baccata in the High Atlas. Yew is rare there and known from a few localities from the Central and Eastern High Atlas (see Suppl. 1). It has not been reported from the Western High Atlas (Culmsee, 2004), where it could occur (Fig. 4B). Historically, T. baccata's first location in the High Atlas was discovered in 1938 by Mr Dubois, a general warden of water and forests, on
Jbel Ahad, on Plateau de l'Iferouane and then reported by Sauvage (1941), Emberger and Maire (1941) and Maire (1952). The next locality in the High Atlas was found by Mr. Fabby, who also worked as a general warden of water and forests. The single yew specimen grows in the N'Fiss valley, close to Sidi Mousa marabout, not far from Moudikht (Emberger \& Maire, 1941; Sauvage, 1943; Maire, 1952; Fennane \& Ibn Tattou, 1998). However, neither of these two populations has been confirmed by herbarium material, nor have they been confirmed in the field in spite of special searching.

The existing localities of the yew in the Central High Atlas have been detected during recent decades near Ahansal, in the gorges of Jbel Aroudane at an altitude of $2300 \mathrm{~m}$ and in the M'Goun massif at an altitude of $2050 \mathrm{~m}$, both sites having been visited by A. Dobignard (personal communication). The presence of $T$. baccata in the Eastern High Atlas was indicated as possible by Emberger (1938), since the more oriental part of the High Atlas shows a great affinity with the Middle Atlas. Indeed, Jbel Ayachi and its surroundings is one of the few areas in the High Atlas where cedars can be found, as mapped by Emberger (1939), with favourable conditions for yews. The final localities from the Eastern High Atlas were reported a few years ago from the National Park of Eastern High Atlas, but without a precise localization (Taleb \& Fennane, 2008).

\section{Occurrence conditions}

The largest contribution (in total 70\%) to the Maxent model had bioclimatic variables based on temperature, especially mean diurnal range of temperature and minimum temperature of the coldest month. Bioclimatic variables based on precipitation had a lower impact on the T. baccata predicted range (in total 30\%). The importance of amplitude and low temperatures is surprising, because the species occurs in much colder climates in the eastern and northern parts of its geographic range (Thomas \& Polwart, 2003; Linares, 2013). However, genetic studies have shown that yew populations in their entire range are diverged into two groups: western (including North Africa) and eastern, with a different demographic history and environmental adaptation during the Pleistocene interglacials (Mayol et al., 2015). Moreover, significant correlations were found among genetic differentiation of western European and northern African populations and annual mean temperature and minimum temperature of the coldest month (Mayol et al., 2015). This confirms the Maxent analysis of yew in the Himalayas, where the minimum temperature of the coldest month determines this species' distribution (Nimasow et al., 2016). However, the Maxent model does not take 
into consideration local conditions, resulting from micro-relief and local wind systems. Taxus baccata is a shade-tolerant tree well adapted to temperate climate conditions, predominantly under the influence of the Atlantic climate. It is sensitive to extremely low temperatures, the influence of continental climate and drought (e.g. Meusel et al., 1965; Thomas \& Polwart, 2003; Schirone et al., 2010). The present-day localities of T. baccata in Morocco are known mostly between altitudes of 1400 and $2000 \mathrm{~m}$, that is, in the layer of humid and semi-humid forests (Peyre, 1983; Charco, 1999, 2007).

The position of almost all the known localities on the north- and/or north-west-facing slopes (Fig. 3) determines first of all the lower level of solar radiation, also lower temperatures and lower evapotranspiration, and thus makes more sustainable conditions for T. baccata and decreases water deficit during the vegetation period (Peyre, 1983; Quézel, 2002; Romo, 2004; Serra, 2007). The north- and north-west-facing slopes are exposed to winds from the Atlantic, which carry a higher level of humidity and cause rain during the vegetation period and snow during winter. The humidity of the soil at the localities of T. baccata is also higher due to occurrence of the species on concave relief forms. The concave and mostly north-facing reliefs are responsible for gathering water courses from rain and accumulating the tiniest soil fractions, preserving water supplies for a longer time than the surrounding areas. This situation illustrates well the occurrence of yew on the northern slopes of the Bou Iblane ridge, which are wetter than the southern, colonized by Juniperus thurifera L. (Romo \& Boratyński, 2005). The presence of T. baccata on the north-facing slopes of Bou Iblane could also be explained by the influence of winds loaded with humidity from the Atlantic and a high level of snow cover (innivation) during winter (Peyre, 1973; Charco, 2007).

The localities of T. baccata in the Rif, especially those in A. maroccana forests, are determined by relatively high precipitation and additionally by mist rising from the Mediterranean Sea in the evenings (Charco, 2007). This phenomenon is said to be causative for the persistence of $A$. maroccana in the Mediterranean climate, relatively dry during the vegetation period (Esteban et al., 2010), and certainly is very advantageous for yew trees. The mists could make possible the existence of T. baccata in the Mediterranean vegetation type at altitudes below 1200$1400 \mathrm{~m}$, and even down to $500 \mathrm{~m}$, as on Jbel Moussa.

Most of the existing localities of $T$. baccata have been preserved on soils developed from rocks containing calcium (e.g. Lecompte, 1969, 1973; Raynaud \& Sauvage, 1974-1978). However, the species also grows on siliceous soils developed from sandstones (Benabid, 1983a, 1984; Deil, 1984; Charco, 1999,
2007). It grows frequently in the fissures of calcareous, and, in some places in the Middle Atlas, also of basaltic, rocks. This kind of site forms quite suitable conditions, as the fissures are filled with clay and humus. Also, a high number of the species' localities were described from shallow soils covered with stones. These types of substrata are fertile and more humid due to evaporation restricted by dense stone cover and dew deposition on the rocks and stones (Olmedo-Cobo \& Gómez-Zotano, 2014). Preferences of this species to limestone were also shown in studies from the whole range (Thomas \& Polwart, 2003; Linares, 2013).

\section{Plant communities}

Taxus baccata was found in riparian shrublands (Ruiz de la Torre, 1956; Raynaud \& Sauvage, 19741978; Quézel, 2002; Fennane, 2003), in forests of $A$. maroccana (Ruiz de la Torre, 1956; Lecompte, 1973) or in C. atlantica forests (Lecompte, 1969; Benabid, 1984). In riparian forests, T. baccata occurs in the association Polysticho setiferi-Prunetum lusitanicae (Barbéro et al., 1981) in the Rif. The subassociation Polysticho setiferi-Prunetum lusitanicae subass. taxetosum was described from Talassemtane National Park (Benabid, 1984). This plant community reaches the Central Rif, where yew occurs on Jbel Tidirhine (Deil, 1984 and personal observations).

As regards coniferous forests, the presence of yew was reported from the cedar forest on Jbel Kelti, described as the association Berberido hispanicae-Cedretum atlanticae (Benabid, 1984) and in the cedar forest of Taffert, northern Bou Iblane range, described as Agropyro marginati-Cedretum atlanticae (Barbéro et al., 1981). In the Tazekka massif and the Central Rif yew was found in the forest of Luzulo forsteri-Cedretum atlanticae (Barbéro et al., 1981). In the fir forest in Talassemtane National Park, it occurs in the association Paeonio maroccanae-Abietetum maroccanae (Barbéro et al., 1981; Benabid, 2000). All these associations are included in the order Querco-Cedretalia atlanticae (Barbéro et al., 1974; Charco, 1999, 2007).

\section{Population structure}

The population of T. baccata in Jebel Lakrâa presented a good health condition and a relatively large number of young individuals, to $24 \mathrm{~cm}$ in height, which indicated successful regeneration. The effective natural regeneration of T. baccata is rare, even among populations that are in the core of the distribution area (Thomas \& Polwart, 2003; Linares, 2013). However, a small number of individuals in height classes from 0.25 to $4.00 \mathrm{~m}$ could indicate a problem with the transition to higher height classes. Field observations indicated that the determining 
factor for a small number of individuals less than 25 $\mathrm{cm}$ high might be the pressure exerted by livestock animals that intensively browse yews, as is the case in many other places in the Mediterranean basin (Farris \& Filigheddu, 2008). In Morocco, intensification of cattle grazing in recent decades has been observed (Davis, 2006), which may be a reason for reduced effective yew regeneration. Individuals in Bekrit in the Middle Atlas were in a much worse state of health, where yew was observed in only three height classes between 4 and $8 \mathrm{~m}$.

The sex ratio of yew trees was male-biased $(37 \%$ females). Unbalanced sex structure may be connected with a deficiency of humidity. It was found that a water deficit may interfere with the sex ratio of yew populations (Iszkuło et al., 2009; Vessella et al., 2015).

\section{Conservation status}

Many years ago, Ruiz de la Torre (1955: 92) commented that: 'Tradicionalmente las maderas de tejo son empleadas sin método ni regla, con la consiguiente pérdida de precio' [Traditionally, yew wood is used without method or legal control, with the resulting loss of value] and this sentence could also explain the regression of T. baccata in Morocco.

Taxus baccata in Morocco is recognized as vulnerable (V) by Fennane and Ibn Tattou (1998) according to the IUCN (2012) criteria and categories. It was also reported as rare (R) from Jbel Tazekka (Fougrach et al., 2007) and from the Rif area (Chambouleyron, 2012). One of the largest populations of yew is conserved in Talassemtane National Park, on the southeast slopes of Jbel Lakrâa and north-west slopes of Jbel Bouchalla. A number of localities were reported from protected areas, such as Jbel Musa National Park near Tanger, and also Tazekka National Park and Ifrane National Park, both in the Middle Atlas, and the Eastern High Atlas National Park (Taleb \& Fennane, 2011). On the national parks' territories T. baccata is preserved against cutting down, but these areas are still used for pasture. Other populations are situated outside of the protected areas (Fennane, 2004), but some of them are located inside the Important Plant Areas of Morocco (Taleb \& Fennane, 2011).

As pointed out by Mathez et al. (1985) and by Linares (2013) for the Mediterranean basin, we found that yew appears as a reduced number of small populations in the Rif and Middle Atlas. The southernmost existing localities in the High Atlas are composed of only a few isolated individuals. Bearing in mind this situation, along with the regression of $T$. baccata within nearly all its geographic range (García et al., 2000; Thomas \& Polwart, 2003; Schirone et al., 2010; Linares, 2013), and taking into account the results of our field searches, there is an urgent need to adopt measures to protect this tree in Morocco, and estimate a possible mechanism of conservation of the gene pool in isolated Moroccan populations (González-Martínez et al., 2010; Jaramillo-Correa et al., 2010).

The southernmost localities of T. baccata, those from the High Atlas, but also all the other ones known from Morocco, are from the 'rear edge' of the geographic range of the species (Hampe \& Petit, 2005). This implies that the Moroccan refugium has probably the most advanced age within the species' geographic range and, following rules described by Hampe and Petit (2005), conserves a high level of regional genetic diversity and differentiation, but a possible low level of genetic diversity within particular populations. Reviewing the accessible genetic data one can find a relatively higher level of genetic differentiation among African populations, higher than among Iberian and Catalan populations, with $F_{S T}$ 1.89, 1.74 and 1.54, respectively (González-Martínez et al., 2010: Table 3). The same data indicated the high level of genetic distinctiveness of North African yew populations from all the others, explained by spatial isolation and a relatively low gene flow by pollen and seeds between populations.

The Pleistocene and earlier climatic changes, with the last hyper-arid period which become established before about $75 \mathrm{ka}$ (Lionello, 2012), caused the restriction of Mediterranean vegetation to a narrow band along the coast and in the mountains receiving higher annual precipitation (Van Andel \& Tzedakis, 1996; Thompson, 2005). The aridification and restriction of T. baccata's geographic range in North Africa also forced possible unusual adaptations to the particular ecological conditions, which resulted from selection influenced by exposition to environmental stresses (Myking et al., 2009; Linares, 2013). Thus, the Moroccan populations of the species shall be conserved and taken under special care.

\section{Acknowledgements}

We would like to express our sincerest thanks to the National Park of Talassemtane Authorities for helping us to carry out the field work, to Alain Dobignard for providing data of localities in the High Atlas where he personally detected the presence of yew and to Ulrich Deil for helping to locate the Rif populations. We would also like to thank Samuel Pyke for linguistic verification of the manuscript. The present study was financially supported by the Institute of Dendrology of the Polish Academy of Sciences (under statutory activity). 


\section{References}

Barbéro M, Loisel R \& Quézel P (1974) Problèmes posés par l'interprétation phytosociologique des Quercetea ilicis et des Quercetea pubescentes. CNRS, Colloques Internationaux du Centre National de la Recherche Scientifique (CNRS) 235: 481-497.

Barbéro M, Quézel P \& Rivas-Martínez S (1981) Contribution à l'étude des groupements forestiers et préforestiers du Maroc. Phytocoenologia 9: 311-412.

Bellakhdar J (1997) La pharmacopée marocaine traditionnelle: Médecine arabe ancienne et savoirs populaires. Ibis Press, Paris, France.

Benabid A (1983a) Études biogéographiques et dynamiques des peuplements foréstiers du Rif (Maroc). Annales de la Recherche Forestière au Maroc 23: 53-128.

Benabid A (1983b) Problèmes posés par l'aménagement sylvopastoral et la préforestation dans le Rif centro-occidental (Maroc). Annales de la Recherche Forestière au Maroc 23: 387-423.

Benabid A (1984) Études phytoécologique des peuplements foréstiers et préforestiers du Rif Centro-occidental (Maroc). Travaux de l'Institut Scientifique, Série Botanique 34: 1-64.

Benabid A (2000) Flore et écosystèmes du Maroc. Évaluation et préservation de la biodiversité. Éditions Ibis Press, Paris, France.

Benkhnigue O, Ben Akka F, Salhi S, Fadli M, Douira A \& Zidane L (2014) Catalogue des plantes médicinales utilisées dans le traitement du diabetes dans la région d'Al Haouz-Rhamne (Maroc). Journal of Animal and Plant Sciences 23: 3539-3568.

Bnouham M, Merhfour FZ, Elachoui M, Legssyer A, Mekhfi H, Lamnaouer D \& Ziyyat A (2006) Toxic effects of some medicinal plants used in Moroccan traditional medicine. Moroccan Journal of Biology 2-3: 21-30.

Browicz K (1982) Chorology of trees and shrubs in south-west Asia and adjacent regions. PWN, Warszawa - Poznań, Poland.

Chambouleyron M (2012) Contribution à la connaissance de la flore de la péninsule tingitane (Maroc). Lagascalia 32: 35-227.

Charco J (1999) El bosque mediterráneo en el Norte de Africa. Agencia Española de Cooperación Internacional, Madrid, Spain.

Charco J (2001) Guía de los árboles y arbustos del Norte de Africa. Agencia Española de Cooperación Internacional, Madrid, Spain.

Charco J (2007) Biogeografía del tejo (Taxus baccata L.) en el norte de África: El tejo en el Mediterráneo occidental: Jornadas Internacionales sobre el tejo y las tejeras en el Mediterráneo occidental (ed. by L Serra) Generalitat Valenciana, Con- selleria de Territori i Habitatge, Alcoy, Spain, pp. 177-183.

Cheddadi R, Bouaissa O, Rhoujjati A \& Dezileau L (2016) Environmental changes in the moroccan western Rif mountains over the last 9,000 years. Quaternaire 27: 15-25. doi:10.4000/quaternaire. 7517

Cheddadi R, Lamb HF, Guiot S \& van der Kaars S (1998) Holocene climatic change in Morocco: a quantitative reconstruction from pollen data. Climate Dynamics 14: 883-890.

Cortés S, Vasco F \& Blanco E (2000) El libro del tejo (Taxus baccata L.). Un proyecto para su conservación. Edita Arba, Madrid, Spain.

Culmsee H (2004) Vegetation und Weidenutzung im westlichen Hohen Atlas (Marokko). Dissertationes Botanicae 389: 1-244.

Davis DK (2006) Neoliberalism, environmentalism, and agricultural restructuring in Morocco. The Geographical Journal 172: 88-105.

Deil U (1984) Zur vegetation im Zentralen Rif (Nordmarokko). Dissertationes Botanicae 74: 1-180.

Devaney JL, Jansen MAK \& Whelan MP (2014) Spatial patterns of natural regeneration in stands of English yew (Taxus baccata L.); Negative neighbourhood effects. Forest Ecology and Management 321: 52-60.

Esteban LG, Palacios P \& Rodríguez-Losada Aguado L (2010) Abies pinsapo forests in Spain and Morocco: threats and conservation. Oryx 44: 276-284. doi:10.1017/S0030605310000190.

Emberger L (1938) Les arbres du Maroc et comment les reconnaître. Larose, Paris, France.

Emberger L (1939) Aperçu général sur la végétation du Maroc. Veröffentlichungen des Geobotanischen Institut Rübel in Zürich 14: 40-157.

Emberger L \& Maire R (1941) Catalogue des plantes du Maroc, vol. 4. Imprimerie Minerva, Alger, Algeria.

Farris E \& Filigheddu R (2008) Effects of browsing in relation to vegetation cover on common yew (Taxus baccata L.) recruitment in Mediterranean environments. Plant Ecology 199: 309-318.

Fennane M (2003) Inventaire des communautés végétales, à l'aide du phytosociologue, au Maroc. Phytosociological checklist of Morocco. Ecologia Mediterranea 29: 87-106.

Fennane M (2004) Propositions de zones importantes pour les plantes au Maroc (ZIP Maroc). Institut Scientifique, Rabat, Morocco.

Fennane M \& Ibn Tattou M (1998) Catalogue des plantes vasculaires rares, menacées ou endémiques du Maroc. Bocconea 8: 5-234.

Fennane M \& Ibn Tattou M (2005) Flore vasculaire du Maroc, vol. 1. Travaux de l'Institut Scientifique, Série Botanique 35: 1-483. 
Fletcher WJ \& Sánchez Goñi MF (2008) Orbital- and sub-orbital-scale climate impacts on vegetation of the western Mediterranean basin over the last 48,000 yr. Quaternary Research 70: 451-464.

Fougrach H, Badri W \& Malki M (2007) Flora vasculaire rare et menacée du Massif de Tazekka (région de Taza, Maroc). Bulletin de l'Institut Scientifique, Rabat. Section Sciences de la Vie 29: 1-10.

García D, Zamora R, Hódar JA, Gómez JM \& Castro J (2000) Yew (Taxus baccata L.) regeneration is facilitated by fleshy-fruited shrubs in Mediterranean environments. Biological Conservation 95: 31-38.

González-Martínez SC, Dubreuil M, Riba M, Vendramin GG, Sebastiani F \& Mayol M (2010) Spatial genetic structure of Taxus baccata L. in the western Mediterranean Basin: Past and present limits to gene movement over a broad geographic scale. Molecular Phylogenetics and Evolution 55: 805815.

Hampe A \& Petit JR (2005) Conserving biodiversity under climate change: the rear edge matters. Ecology Letters 8: 461-467.

Hijmans RJ, Cameron SE, Parra JL, Jones PG \& Jarvis A (2005) Very high resolution interpolated climate surfaces for global land areas. International Journal of Climatology 25: 1965-1978. doi: 10.1002/joc. 1276.

Hultén E \& Fries M (1986) Atlas of north European vascular plants. Koeltz Scientific Books, Königstein, Germany.

Iszkuło G \& Jasińska AK (2004) Variation in sex expression in Polish and Ukrainian populations of Taxus baccata L. Dendrobiology 52: 29-32.

Iszkuło G, Jasińska AK, Giertych MJ \& Boratyński A (2009) Do secondary sexual dimorphism and female intolerance to drought influence the sex ratio and extinction risk of Taxus baccata? Plant Ecology 200: 229-240.

Iszkuło G, Pers-Kamczyc E, Nalepka D, Rabska M, Walas Ł \& Dering M (2016) Postglacial migration dynamics helps to explain current scattered distribution of Taxus baccata. Dendrobiology 76: 81-89.

IUCN (2012) IUCN Red List categories and criteria: version 3.1. Cambridge, England.

Jahandiez E \& Maire R (1931) Catalogues de plantes du Maroc, vol. 1. Imprimerie Minerva, Alger, Algeria.

Jalas J \& Suominen J (1973) Atlas Florae Europaeae, vol. 2. The Committee for Mapping the Flora of Europe and Societas Biologica Fennica Vanamo, Helsinki, Finland.

Jaramillo-Correa JP, Grivet D, Terrab A, Kurt Y, De-Lucas AI, Wahid N, Vendramin GG \& González-Martínez SC (2010) The Strait of Gibraltar as a major biogeographic barrier in Medi- terranean conifers: a comparative phylogeographic survey. Molecular Ecology 19: 5452-5468.

Lamb HF, Damblon F \& Maxted RW (1991) Human impact on the vegetation of the Middle Atlas, Morocco, during the last 5000 years. Journal of Biogeography 18: 519-532.

Lamb HF \& van der Kaars S (1995) Vegetational response to Holocene climatic change: pollen and palaeolimnological data from the Middle Atlas, Morocco. The Holocene 5: 400-408.

Lecompte M (1969) La végétation du Moyen Atlas central. Travaux de l'Institut Scientifique Chérifien, série Botanique 31: 1-31.

Lecompte M (1973) Aperçu sur la végétation dans Le Rif occidental calcaire (Massif de Talassemtane). Travaux Recherche Coopérative Publique 249 CNRS 1: 89-104.

Linares JC (2013) Shifting limiting factors for population dynamics and conservation status of the endangered English yew (Taxus baccata L., Taxaceae). Forest Ecology and Management 291: 119-127.

Lionello P (2012) The climate of the Mediterranean region. Elsevier, Amsterdam, Holland.

Lionello P, Abrantes F, Gacic M, Planton S, Trigo R \& Ulbrich U (2014) The climate of the Mediterranean region: research progress and climate change impacts. Regional Environmental Change 14: 1679-1684. doi:10.1007/s10113-014-0666-0.

Maire R (1952) Flore de l'Afrique du Nord, vol. 1. Lechevalier, Paris, France.

Mayol M, Riba M, González-Martínez SC, Bagnoli F, de Beaulieu J-L, Berganzo E, Burgarella C, Dubreuil M, Krajmerová D, Paule L, Romšáková I, Vettori C, Vincenot L \& Vendramin GG (2015) Adapting through glacial cycles: insights from a long-lived tree (Taxus baccata). New Phytologist 208: 973-986. doi:10.1111/nph.13496.

Mathez J, Quézel P \& Raynaud C (1985) The Maghreb countries: Plant conservation in the Mediterranean area (ed. by C Gomez-Campo) Junk Publishers, Dordrecht, Netherlands.

Meusel H, Jäger E \& Weinert E (1965) Vergleichende chorologie der zentraleuropäischen flora, vol. 1. G. Fischer, Jena, Germany.

Myking T, Vakkari P \& Skrøppa T (2009) Genetic variation in northern marginal Taxus baccata L. populations. Implications for conservation. Forestry 82: 529-539.

Nimasow G, Nimasow OD, Rawat JS, Tsering G \& Litin T (2016) Remote sensing and GIS-based suitability modeling of medicinal plant (Taxus baccata Linn.) in Tawang district, Arunachal Pradesh, India. Current Science 110: 219-227.

Olmedo-Cobo JA \& Gómez-Zotano J (2014) El tejo en el sur de España: análisis geoecológico y propuesta de conservación de una población medi- 
terránea en peligro crítico de extinción. Bosque 35: 23-36.

Peyre C (1973) Quelques aspects de la végétation du massif du Bou Iblane. CNRS. Travaux de la Recherche Coopérative Publique 249: 129-147.

Peyre C (1983) Étagement de la végétation et gradients climatiques dans le système Atlasique Marocain. Le bassin de l'Oued Rdat et le versant sud de l'Atlas au Méridien du Tizi N'Tichka. Bulletin de la Faculté des Sciences de Marrakech (Section Sciences de la Vie) 2: 87-139.

Phillips SJ, Anderson RP \& Schapire RE (2006) Maximum entropy modeling of species geographic distributions. Ecological Modelling 190: 231-259.

Pridnya MV (1984) Phytocenotic status and structure of the Khosta common yew population in the Caucasus Biosphere Reserve. Soviet Journal of Ecology 15: 1-6.

Quézel P (2002) Réflexions sur l'évolution de la flore et de la végétation au Maghreb méditerranéen. Ibis, Paris, France.

Raynaud C \& Sauvage C (1974-1978) Catalogue des végétaux vasculaires du Talassemtane (Rif occidental). Travaux Recherche Coopérative Publique 249 CNRS 2: 209-230; 3: 143-178; 4: 149-204.

Romo AM (2004) Biogeografía de la vegetación en las montañas de Marruecos: Estudios en Biogeografía (ed. by JM Panareda, ME Arozena, C Sanz \& N López) Aster, Terrassa, Spain, pp. 89-96.

Romo A \& Boratyński A (2005) Chorology of Juniperus thurifera (Cupressaceae) in Morocco. Dendrobiology 54: 41-50.

Ruiz B, Gil MJ \& Duque D (2014) Vegetation history in the Oukaïmedene Valley. Human action and evolution of the landscape. Complutum 25: 123-137.

Ruiz de la Torre J (1955) El matorral en Yebala (Marruecos Español). Instituto de Estudios Africanos CSIC, Madrid, Spain.

Ruiz de la Torre J (1956) La vegetación natural del Norte de Marruecos y la elección de especies para su repoblación forestal. Servicio de Montes, Centro de Investigaciones y Experiencias Forestales, Larache, Morocco.

Sauvage Ch (1941) L'if dans le Grand Atlas. Bulletin de la Société des Sciences Naturelles du Maroc 21: 82-90.

Sauvage Ch (1943) Annotations au catalogue des plantes du Maroc. Bulletin de la Société des Sciences Naturelles du Maroc 23: 127-140.
Schirone B, Ferreira RC, Vessella F, Schirone A, Piredda R \& Simeone MC (2010) Taxus baccata in the Azores: a relict form at risk of imminent extinction. Biodiversity Conservation 19: 1547-1565. doi: 10.1007/s10531-010-9786-0.

Serra L (2007) El tejo en el Mediterráneo occidental. Jornadas Internacionales sobre el tejo y las tejeras en el Mediterráneo occidental. Generalitat Valenciana, Conselleria de Territori i Habitatge, Alcoy, Spain.

Takhtajan A (1986) Floristic regions of the world. (translated by TJ Crovello \& A Cronquist) University of California Press, Berkeley, USA.

Taleb MS \& Fennane M (2008) Diversité floristique du Parc National du Haut Atlas Oriental et des massifs Ayachi et Maâsker (Maroc). Acta Botanica Malacitana 33: 125-145.

Taleb MS \& Fennane M (2011) Morocco: important plant areas of the South and East Mediterranean region: priority sites for conservation (ed. by A Radford, G Catullo \& B de Montmollin), IUCN, Gland, Switzerland and Malaga, Spain, pp. 22-26.

Thomas PA \& Polwart A (2003) Taxus baccata L. Journal of Ecology 91: 489-524.

Thompson JD (2005) Plant evolution in the Mediterranean. Oxford University Press, Oxford, England.

Van Andel TH \& Tzedakis PC (1996) Paleolithic landscapes of Europe and environs, 150,000-25,000 years ago: an overview. Quaternary Science Review 15: 481-500.

Vessella F, Simeone MC, Fernandes FM, Schirone A, Gomes MP \& Schirone B (2013) Morphological and molecular data from Madeira support the persistence of an ancient lineage of Taxus baccata L. in Macaronesia and call for immediate conservation actions. Caryologia 66: 162-177. doi: 10.1080/00087114.2013.821842.

Vessella F, Salis A, Scirè M, Piovesan G \& Schirone B (2015) Natural regeneration and gender-specific spatial pattern of Taxus baccata in an old-growth population in Foresta Umbra (Italy). Dendrobiology 73: 75-90.

Zapata L, López-Sáez JA, Ruiz-Alonso M, Linstädter J, Pérez-Jordà G, Morales J, Kehl M \& Peña-Chocarro L (2013) Holocene environmental change and human impact in NE Morocco: Palaeobotanical evidence from Ifri Oudadane. The Holocene 23: 1286-1296. doi: 10.1177/0959683613486944. 